\title{
Experiences of Teaching Computer Network Course through Lesson Outcomes
}

\author{
Abhishek Vichare, Prathamesh P. Churi
}

\begin{abstract}
National Board of Accreditation (Abbreviated as $N B A$ ) is an official and independent accreditation body of India. Many engineering colleges must adhere to the quality requirements as per the $\mathrm{NBA}$ guidelines. Every engineering institute must prepare a Self-Assessment Report (SAR) and submit it to a peer review team for getting NBA Accreditation. In recent years NBA has changed input-output based traditional education system to Outcome-Based Education (OBE). OutcomeBased Education is an approach where each course can have atleast $N$ number of outcomes that students will learn at the end of the semester for a particular course. Later on, these course outcomes can be mapped with Program Outcomes (PO) and Program Educational Objectives (PEO). According to the NBA, $C O$ 's are the most granular level of objects that can be defined over a particular course. The problem with particular $\mathrm{CO}$ is that they are much generalized and can be mapped to 2-3 chapters of the same course. It becomes very difficult to assess student based on a particular $\mathrm{CO}$. The solution is provided in this paper by dividing CO's in further lesson Outcomes (LO) for effective teaching-learning. The paper also takes a real case study of course - Computer Networks which is an undergraduate course of Mukesh Patel School of Technology Management and Engineering (MPSTME, Affiliated to NMIMS University). After defining LO's of the said course, the paper shows different Course Exit Survey Records in a graphical manner for better understanding. The methodology defined by author outperforms the current existing method defining CO's.
\end{abstract}

Keywords- OBE; outcome-based system; learning outcomes; SAR

\section{INTRODUCTION}

National Board of Accreditation (Abbreviated as NBA) is an official and independent accreditation body of India. Many engineering colleges must adhere to the quality requirements as per the NBA guidelines. Every engineering institute must prepare a Self-Assessment Report (SAR) and submit it to a peer review team for getting NBA Accreditation. In recent years NBA has changed input-output based traditional education system to Outcome-Based Education (OBE). OBE is defined as a methodology in which every course is defined by a particular outcome. And the outcome is a result of the assessment which every student earns after the end of every semester for a particular course.

Revised Manuscript Received on September 10, 2019.

Abhishek Vichare, Computer Engineering Department, Mukesh Patel School of Technology Management and Engineering, NMIMS University, Mumbai, India, Abhishek.vichare@nmims.edu

Prathamesh Churi, Computer Engineering Department, Mukesh Patel School of Technology Management and Engineering, NMIMS University, Mumbai, India, Prathamesh.churi@nmims.edu

Traditional Education system has input-output based strategy in which students are evaluated based upon certain inputs in terms of mugging up the contents of the course, memorizing equations and theorems and outputs them in the

final examination. The traditional education system does not taste the knowledge, rather it just tests your memory. On another side, the traditional education system does not provide a suitable learning environment which is favorable for industry requirements. There is always a huge gap between industry and education in India. Several types of research speak about the gap between industry and education system [21, 22, 23, 24, 25]. Another aspect of traditional education is that it emphasizes student on rote learning [26, 27] and it does not define a proper strategy for teaching and learning.

On the other side, OBE is experienced based teachinglearning approach and based on ISO 9000 principles of continuous quality improvement (CQI) which was defined according to requirements of the industry. The first implementation of OBE was in USA [28, 29]. The industry is happier with the graduates that they are recruiting and the society is gaining more involved global citizens [4]. NBA has adopted the principles of OBE aiming at the fact that Indian students will get recognition not only in industry but at international level where product research and development is important.

Self-Assessment Report (SAR) emphasizes on Course Outcomes (CO), Program Outcomes (PO) as well Program Educational Objectives (PEO). As per the NBA SAR, PO attainment is done on the basis of CO. For each course, there are three to six-course outcomes, which are mapped with predefined PO's. Many researchers, academicians have proposed and proved methods for this mapping from $\mathrm{CO}$ to PO. But there is scope to map Learning outcomes of each unit/lecture/session with CO.

Different assessment tools are used to measure student performance and $\mathrm{CO}$ attainment. Similar methods can be used for LO attainment.

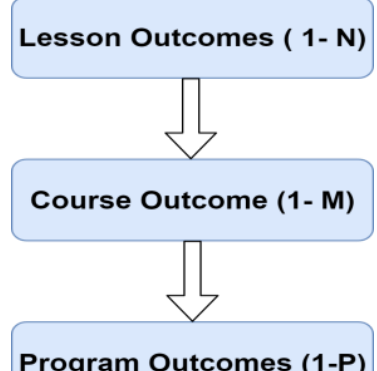

Fig. 1. Role of Lesson Outcomes in OBE 
NBA Requirement to achieve PO

- Define Course Outcomes.

- Perform Course Outcomes attainment.

- Map Course Outcomes attainment with predefined PO.

The proposed method to achieve PO-1. Define Lesson Outcomes (LO's)

- Prepare attainment of LO's. (This can be done in similar way CO's are attained.)

- Perform CO attainment.

- Map CO attainment with predefined PO.

\section{Outcomes Preparation}

\section{A. Program Educational Objectives(PEO)}

PEO is the feasible statement/s that describes the expected objectives of any graduate student within a few years of graduate study from the desired program [9]. Ideal characteristics of PEO is as follows :

- PEO's are real time and must be achievable enough.

- PEO statement must not be too long and must be simple and clear to understand.

- The PEO must satisfy the global and societal needs, parallel to vision and mission of the institute, etc.

- While defining PEO's, every institute must involve stakeholders like employers, industrialist, alumni, students, etc.

\section{B. Program Outcomes [18,19,20]}

The Accreditation Board for Engineering and Technology (ABET) defines Program Learning Outcomes as "statements that describe what students are expected to know and be able to do by the time of graduation. [30, 31]"

The above definition is about testing skills, knowledge and attitude of graduate expected at the completion of the program. Like the NBA, ABET has the mapping of all Students Outcomes (SO) to corresponding course outcomes. Based on these graduate attributes, the NBA has also mentioned twelve PO (program Outcomes) in their selfassessment report format. There is a lot of research has been cited about how to make effective CO's and PO's [32, 33].

\section{Course Outcomes}

Course outcomes are the feasible statements which define the learning expectation and outcome of a student at the end of the course. The course outcome is the heart of OBE which is then mapped with PO's. course outcomes are generally defined by faculty and verified by concern domain expert of the institution. There is as such no limit of defining course outcomes but for better learning maximum 4-6 outcomes are better.

\section{Preparing Lesson Outcomes}

A new approach of this paper is a lesson outcome (LO) which can be defined as a simple statement which reflects the outcome of a lesson. A lesson is a small topic and has a limited scope of learning. The group of LO's constitutes Course Outcomes (CO's). LO's are considered as the lowest form of making outcomes [7].

Lesson outcomes for each lesson may play an integral role in achieving course outcomes. The mapping process of
LO to $\mathrm{CO}$ is the same as the mapping process of $\mathrm{CO}$ to PO. There are three broad types of learning outcomes according to [34] :

- Disciplinary knowledge and skills

- Generic skills

- Attitudes and values

1. Use of simple and specific action verbs

According to blooms taxonomy [11, 12], Action words help to define an appropriate method for any outcome which can be satisfied over a period of time. In this step, the focus must be on student behavior and simple, specific action verbs must be used to describe what students are expected to demonstrate.

The action verb helps to structure the alignment of any graduate program and course outcomes as well as lesson outcomes with all the feasible assessment that are defined over course[7]. The detailed blooms taxonomy action verbs are given in $[11,12]$

\section{Select the appropriate assessment method}

According to $[9,10]$ assessment methods are different ways to determine whether learning outcomes are achieved. Few examples of assessment methods are listed in [35]

A number of assessment procedures are available for Course Outcomes and Program Outcomes[13, 14, 15]. Similar procedures can be used with respect to Lesson Outcomes.

\section{MAPPING LesSon OUTCOMES With COURSE OUTCOMES- A CASE STUdY FOR COMPUTER NeTWORKS COURSE}

In order to explain the two steps which are defined in Section III, authors have taken the course "Computer Networks" which is an official course at NMIMS UniversitySchool of Engineering - B.Tech in Computer Engineering Program.

The credit structure prerequisite for Computer Networks course is given in Table I below.

TABLE I. CREDIT STRUCTURE OF COMPUTER NETWORKS

\begin{tabular}{|c|c|c|c|c|c|}
\hline $\begin{array}{l}\text { Progr } \\
\text { am : }\end{array}$ & \multicolumn{3}{|c|}{$\begin{array}{l}\text { B. Tech. (Computer } \\
\text { Engineering) }\end{array}$} & \multicolumn{2}{|c|}{ Semester: IV } \\
\hline $\begin{array}{c}\text { Cours } \\
\text { e }\end{array}$ & \multicolumn{3}{|c|}{ Computer Networks } & \multicolumn{2}{|c|}{$\begin{array}{l}\text { Code } \\
\text { :BTCO04004 }\end{array}$} \\
\hline \multicolumn{4}{|c|}{ Teaching Scheme } & \multicolumn{2}{|c|}{ Evaluation Scheme } \\
\hline $\begin{array}{l}\text { Lect } \\
\text { ure } \\
\text { Hour } \\
\text { s per } \\
\text { week }\end{array}$ & $\begin{array}{l}\text { Pract } \\
\text { ical } \\
\text { Hour } \\
\text { s per } \\
\text { week }\end{array}$ & $\begin{array}{l}\text { Tutor } \\
\text { ial } \\
\text { Hour } \\
\text { s per } \\
\text { week }\end{array}$ & Credit & $\begin{array}{c}\text { Theory } \\
(3 \\
\text { Hours, } \\
70 \\
\text { Marks })\end{array}$ & $\begin{array}{c}\text { Internal Continuous } \\
\text { Assessment (ICA) } \\
\text { As per Institute } \\
\text { Norms } \\
\text { ( 50 marks) }\end{array}$ \\
\hline 3 & 2 & 0 & 4 & $\begin{array}{l}\text { Scaled } \\
\text { to } \\
70 \\
\text { marks }\end{array}$ & Scaled to 30 marks \\
\hline \multicolumn{6}{|c|}{ Pre-requisite: Data Structures(BTCO03002) } \\
\hline $\begin{array}{r}\text { Objec } \\
\text { netw }\end{array}$ & s: $\mathrm{Tl}$ & ourse p & $\begin{array}{r}\text { vides th } \\
\text { rstandin } \\
\mathrm{m}\end{array}$ & $\begin{array}{l}\text { fundamen } \\
\text { of the ISC } \\
\text { el. }\end{array}$ & $\begin{array}{l}\text { knowledge of computer } \\
\text { SI model and TCP-IP }\end{array}$ \\
\hline
\end{tabular}

Course outcomes defined for subject Course Outcomes are as follows in Table I : 
TABLE II.

COURSE OUTCOMES OF COMPUTER NETWORKS

\begin{tabular}{|l|l|}
\hline $\begin{array}{c}\text { Course } \\
\text { Outcome }\end{array}$ & \multicolumn{1}{|c|}{ Statement } \\
\hline $\mathrm{CO} 1$ & $\begin{array}{l}\text { Discuss the fundamentals of computer networks, their types, } \\
\text { transmission modes, and different reference models. }\end{array}$ \\
\hline $\mathrm{CO} 2$ & $\begin{array}{l}\text { Implement error-free transmission of data and analyze data } \\
\text { collision with various protocols. }\end{array}$ \\
\hline $\mathrm{CO} 3$ & $\begin{array}{l}\text { Implement various routing and congestion control algorithms } \\
\text { over a network. }\end{array}$ \\
\hline $\mathrm{CO} 4$ & $\begin{array}{l}\text { Identify Quality of service parameters and addressing } \\
\text { techniques. }\end{array}$ \\
\hline $\mathrm{CO} 5$ & Understand the working of application layer protocols. \\
\hline
\end{tabular}

The contents of the course syllabus are given in Table III.

TABLE III.

SYLLABUS CONTENTS OF COMPUTER NETWORKS

\begin{tabular}{|c|c|c|}
\hline Unit & Description & Duration \\
\hline 1 & $\begin{array}{l}\text { Introduction: } \\
\text { Communicating in a network-centric world, } \\
\text { network as a platform, Architecture of the } \\
\text { internet, Classification of Networks, Layered } \\
\text { Models, Network Addressing, components } \\
\text { of the network, topology, and transmission } \\
\text { mode, Internetworking devices }\end{array}$ & 06 \\
\hline 2 & $\begin{array}{l}\text { The Physical Layer: } \\
\text { Communication Signals, Purpose of the } \\
\text { Physical Layer, Physical Layer Operation, } \\
\text { Physical Layer Standards, Physical } \\
\text { Signaling, and Encoding Physical Media: } \\
\text { Types of Physical Media and Media } \\
\text { Connectors, Performance, Circuit, and } \\
\text { Packet Switching The Public Switched } \\
\text { Telephone Network, Cable Television. }\end{array}$ & 05 \\
\hline 3 & $\begin{array}{l}\text { The Data Link Layer: } \\
\text { Data link layer design issues, error detection, } \\
\text { and correction, elementary data link } \\
\text { protocols, Sliding Window Protocols, } \\
\text { Example of Data Link Protocol: HDLC. }\end{array}$ & 06 \\
\hline 4 & $\begin{array}{l}\text { Medium Access Sub-layer: } \\
\text { The channel allocation problem, Multiple } \\
\text { Access Protocols, Ethernet, Data link layer } \\
\text { switching. }\end{array}$ & 06 \\
\hline 5 & $\begin{array}{l}\text { The Network Layer: } \\
\text { Network Layer Design issues, Routing } \\
\text { Algorithms, Congestion Control Algorithms, } \\
\text { and Quality of Service, X.25 and Frame } \\
\text { Relay architecture. IPv4, IPv4 Addressing. }\end{array}$ & 08 \\
\hline 6 & $\begin{array}{l}\text { The Transport Layer: } \\
\text { Introduction to TCP, The TCP Service, } \\
\text { Elements of Transport Protocols, A simple } \\
\text { Transport Protocol, The TCP Segment } \\
\text { Header, Connection Establishment, } \\
\text { connection release, Modeling TCP } \\
\text { Management. The Transport: UDP, } \\
\text { Performance Issues. }\end{array}$ & 08 \\
\hline 7 & $\begin{array}{l}\text { The Application Layer: } \\
\text { DNS, E-Mail Services and SMTP/POP } \\
\text { Protocols, File Transfer Protocol (FTP), } \\
\text { WWW Service and HTTP, Multimedia, } \\
\text { SNMP Protocol. }\end{array}$ & 06 \\
\hline & $\begin{array}{r}\text { Total } \\
\end{array}$ & 45 \\
\hline \multicolumn{3}{|c|}{$\begin{array}{l}\text { Text Books: } \\
\text { - } \quad \text { Andrew S. Tanenbaum, "Computer Networks", Pearson } \\
\text { Education, Fourth Edition, 2009. } \\
\text { B.F. Forouzan, "Data Communications and Networking", } \\
\text { TMH, second edition, 2008. }\end{array}$} \\
\hline & $\begin{array}{l}\text { ce Books: } \\
\text { rk Dye et.al, "Network Fundamentals", CCNA } \\
\text { mpanion Guide, Cisco Press, } 2011 . \\
\text { rose, Ross, "Computer Networking: A } \\
\text { proach ", 5th Edition, 2009, Pearson Education. } \\
\text { E. Comer, "Computer Networks with }\end{array}$ & $\begin{array}{r}\text { Exploration } \\
\text { Top-Down } \\
\text { Internet } \\
\end{array}$ \\
\hline
\end{tabular}

Applications", $5^{\text {th }}$ edition, Prentice Hall, 2008.

- B.F. Forouzan, "TCP/IP Protocol Suite", TMH, Fourth edition, 2010.

Internal Continues Assessment Structure of Course Computer Networks is given in Table IV below:

\section{TABLE IV. INTERNAL ASSESSMENT FOR COMPUTER NETWORKS COURSE}

Term Work: As per the Internal Continuous Assessment (ICA) norms of the Institute

1. Minimum 10 practical experiments covering all the topics.

2. Minimum two Assignments covering the syllabus content.

3. Two class tests ( 15 marks each)

Table V contains individual chapter associated with corresponding course outcomes.

TABLE V. MAPPING CHAPTERS WITH COURSE OUTCOMES OF COMPUTER NETWORKS

\begin{tabular}{|c|l|l|}
\hline $\begin{array}{c}\text { Chapter } \\
\text { Number }\end{array}$ & \multicolumn{1}{|c|}{ Chapter Name } & $\begin{array}{c}\text { Course } \\
\text { Outcome }\end{array}$ \\
\hline 1 & Introduction & $\mathrm{CO} 1$ \\
\hline 2 & Physical Layer & $\mathrm{CO} 1$ \\
\hline 3 & Data Link Layer & $\mathrm{CO} 2$ \\
\hline 4 & Medium Access Sub Layer & $\mathrm{CO} 2$ \\
\hline 5 & Network Layer & $\mathrm{CO} 3 \mathrm{CO} 4$ \\
\hline 6 & Transport Layer & $\mathrm{CO} 3 \mathrm{CO} 4$ \\
\hline 7 & Application Layer & $\mathrm{CO} 5$ \\
\hline
\end{tabular}

Mapping of learning outcomes to course outcomes for subject Computer Networks is done in the following manner.

Table VI and VII show the mapping of learning outcomes with course outcomes for a few topics. This is an attempt made to enhance the granularity level of the said course outcome.

TABLE VI. MAPPING COURSE OUTCOMES TO LESSON OUTCOMES FOR CHAPTER 1 - COVERS CO1

\begin{tabular}{|c|l|l|l|}
\hline $\begin{array}{c}\text { Chapter } \\
\text { No. }\end{array}$ & \multicolumn{1}{|c|}{ Topic name } & \multicolumn{1}{|c|}{ Learning Outcome } & \multicolumn{1}{c|}{$\begin{array}{c}\text { Course } \\
\text { Outcome }\end{array}$} \\
\hline $\begin{array}{c}\text { Total } \\
\text { Duration } \\
-6 \mathrm{Hrs}\end{array}$ & $\begin{array}{l}\text { Communicating } \\
\text { in network- } \\
\text { centric world, } \\
\text { network as a } \\
\text { platform, } \\
\text { Architecture of } \\
\text { the internet }\end{array}$ & $\begin{array}{l}\text { LO1- Recognise the } \\
\text { importance of network- } \\
\text { centric world by the } \\
\text { understanding architecture } \\
\text { of the Internet. }\end{array}$ & CO1 \\
\cline { 2 - 5 } & $\begin{array}{l}\text { Classification of } \\
\text { networks, } \\
\text { topology }\end{array}$ & $\begin{array}{l}\text { LO2-Classify and compare } \\
\text { different types of network } \\
\text { based on physical size, } \\
\text { geographical location, and } \\
\text { communication type. }\end{array}$ & CO1 \\
\cline { 2 - 5 } & $\begin{array}{l}\text { Layered Models, } \\
\text { network }\end{array}$ & $\begin{array}{l}\text { LO3-Describe and compare } \\
\text { ISO-OSI and TCP/IP } \\
\text { network model. }\end{array}$ & CO1 \\
\cline { 2 - 5 } & $\begin{array}{l}\text { Addressing, } \\
\text { components of } \\
\text { and transmission } \\
\text { mode, }\end{array}$ & $\begin{array}{l}\text { LO4- Understand different } \\
\text { addressing techniques and } \\
\text { transmission modes of a } \\
\text { network. CO1 }\end{array}$ & \\
\hline
\end{tabular}




\begin{tabular}{|l|l|l|}
\hline $\begin{array}{l}\text { Internetworking } \\
\text { devices }\end{array}$ & $\begin{array}{l}\text { LO5- Select appropriate } \\
\text { networking devices based } \\
\text { upon the case study given. }\end{array}$ & CO1 \\
\hline
\end{tabular}

From table VI, It is clear that the generalized course outcome is divided into specific lesson outcomes. The granularity level reflects the following aspect of the said research:

- It helps to select appropriate pedagogy for a specific lesson instead of a specific chapter. For example: from table VI, the topic name- Internetworking devices, we have arranged a tour of network lab of our university to our undergraduate students. Whereas for the topic name- Layered Model, we have shown a graphical presentation of ISO OSI and TCP/IP model for to the class. Instead of sticking to only pedagogy per course outcome, It helped to use different pedagogy as per the changing lesson outcomes of the same course outcome.

- It helps to select the appropriate assessment tool for a specific lesson instead of a specific chapter. For example, from Table VI, the topic name Internetworking devices, we have conducted the quiz about which internetworking devices can work on which layer of the ISO OSI layer. Whereas for the topic name- Layered Model, we have asked a question on the differentiation between the ISO/OSI model and TCP/IP model. It helped to use different assessment tool as per the changing lesson outcomes of same course outcome.

From table V, It can be seen that CO 1 covers 2 chapters. Table VI shows the mapping of lesson outcomes to course outcomes for chapter 1, Therefore table VII shows the mapping of lesson outcomes to course outcomes for chapter 2.

TABLE VII. MAPPING COURSE OUTCOMES TO LESSON OUTCOMES FOR CHAPTER 2 - COVERS CO1

\begin{tabular}{|c|c|c|c|}
\hline $\begin{array}{c}\text { Chapter } \\
\text { No. }\end{array}$ & Topic name & Learning Outcome & $\begin{array}{l}\text { Course } \\
\text { Outcome }\end{array}$ \\
\hline \multirow[t]{5}{*}{$\begin{array}{c}2 \\
\text { Total } \\
\text { Duration } \\
-5 \mathrm{Hrs}\end{array}$} & $\begin{array}{l}\text { Communication } \\
\text { Signals, Purpose } \\
\text { of the Physical } \\
\text { Layer, Physical } \\
\text { Layer Operation, } \\
\text { Physical Layer } \\
\text { Standards. }\end{array}$ & $\begin{array}{l}\text { LO6- Understand the } \\
\text { purpose, operation, and } \\
\text { standards of the Physical } \\
\text { layer. }\end{array}$ & $\mathrm{CO} 1$ \\
\hline & $\begin{array}{l}\text { Physical } \\
\text { Signaling and } \\
\text { Encoding }\end{array}$ & $\begin{array}{l}\text { LO7- Identify and explain } \\
\text { appropriate signaling } \\
\text { methods to the given } \\
\text { problem. }\end{array}$ & $\mathrm{CO} 1$ \\
\hline & $\begin{array}{lr}\text { Physical } & \text { Media: } \\
\text { Types } & \text { of } \\
\text { Physical Media } \\
\text { and } & \text { Media } \\
\text { Connectors, }\end{array}$ & $\begin{array}{l}\text { LO8- Describe different } \\
\text { types of physical media and } \\
\text { media connectors. }\end{array}$ & $\mathrm{CO} 1$ \\
\hline & $\begin{array}{l}\text { Circuit and } \\
\text { Packet Switching }\end{array}$ & $\begin{array}{l}\text { LO9- Differentiate between } \\
\text { circuit switching and } \\
\text { packet switching. }\end{array}$ & $\mathrm{CO} 1$ \\
\hline & $\begin{array}{l}\text { The public } \\
\text { switched } \\
\text { Telephone } \\
\text { Network, Cable }\end{array}$ & $\begin{array}{l}\text { LO10- Describe the } \\
\text { working of Public Switch } \\
\text { Telephone Network and } \\
\text { cable television }\end{array}$ & $\mathrm{CO} 1$ \\
\hline
\end{tabular}

From table VI and VII, Total 10 lesson outcomes are listed from course outcome - I. Similar work is also done for other course outcomes.

\section{RESUlt AND ANALYSIS THROUGH A COURSE EXIT SURVEY}

At the end of the semester, the course exit survey of the subject is taken. The questionnaire was also kept based upon the lesson outcomes. The mode of collecting responses from students made online. The sample list of a questionnaire for CO1 is given in the table below. The rating has been kept from 4 to 1 whereas 4- Very Good, 3- Good, 2-Satisfactorily and 1-Poor.

TABLE VIII. QUESTIONNAIRE FOR CO1 - COMPUTER NETWORKS

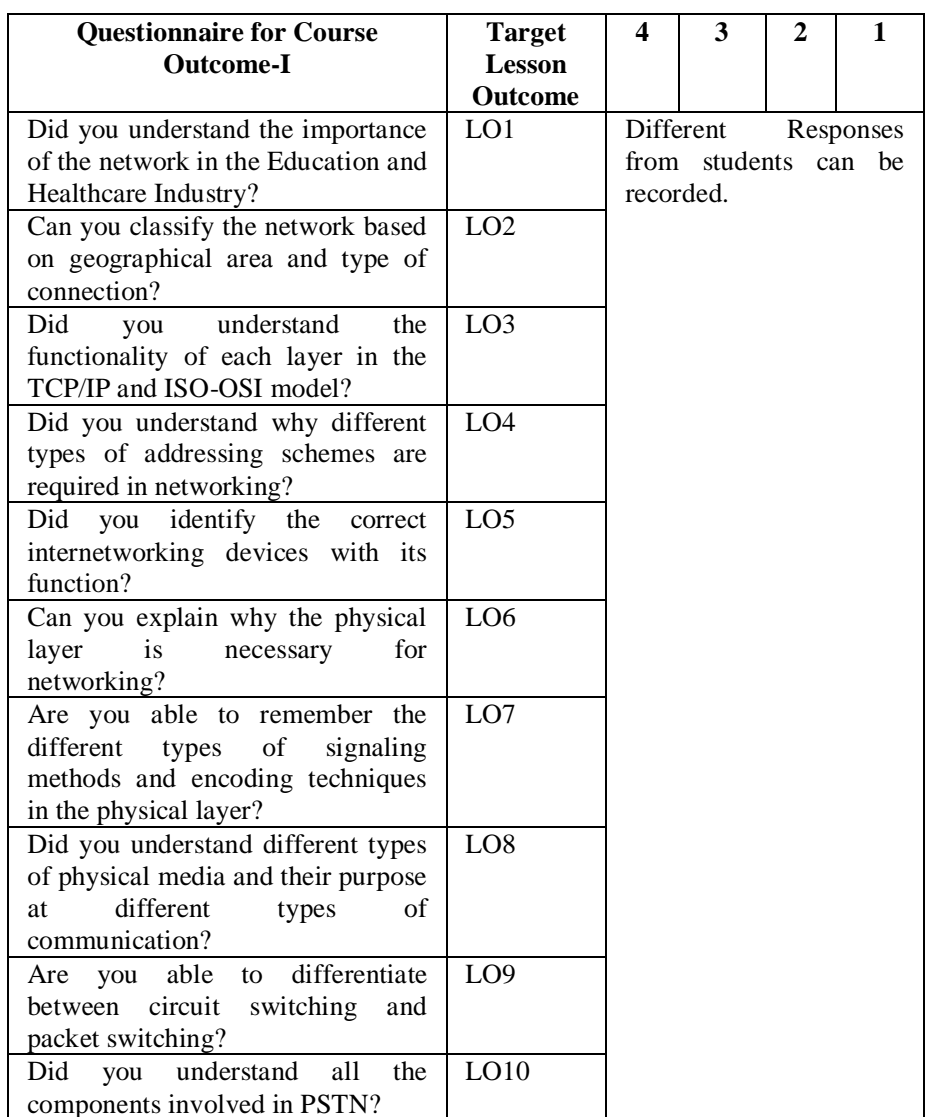

We have made such a form for all course outcomes. An online form (given in table VIII) is circulated among students and the response of each lesson outcome is recorded. Table IX, X, XI, XII, XIII holds students responses of each course outcome. For course outcome- I, II, III, IV, V total 58, 54, 56, 51, 49 students have participated respectively. Table XIV represents, the consolidated average score of individual course outcome rating based on individual lesson outcome. 
TABLE IX. $\quad$ COURSE EXIT SURVEY FOR COURSE OUTCOME -I

\begin{tabular}{|c|c|c|c|c|c|c|c|c|c|c|c|}
\hline Lesson Outcomes for CO1 & LO1 & $\mathbf{L O 2}$ & $\mathbf{L O 3}$ & LO4 & LO5 & LO6 & LO7 & LO8 & LO9 & LO10 & $\begin{array}{c}\text { The average } \\
\text { number of students } \\
\text { for CO1 }\end{array}$ \\
\hline $\begin{array}{l}\text { Total Number of Students } \\
\text { Participated in Survey }\end{array}$ & 58 & 58 & 58 & 58 & 58 & 58 & 58 & 58 & 58 & 58 & 58 \\
\hline $\begin{array}{c}\text { Total Number of Students who } \\
\text { have marked } 4\end{array}$ & 28 & 26 & 28 & 29 & 29 & 28 & 25 & 21 & 31 & 19 & 26 \\
\hline $\begin{array}{c}\text { Total Number of Students who } \\
\text { have marked } 3\end{array}$ & 29 & 23 & 30 & 22 & 21 & 29 & 25 & 29 & 21 & 21 & 25 \\
\hline $\begin{array}{c}\text { Total Number of Students who } \\
\text { have marked } 2\end{array}$ & 1 & 7 & 1 & 4 & 4 & 1 & 7 & 7 & 5 & 10 & 5 \\
\hline $\begin{array}{c}\text { Total Number of Students who } \\
\text { have marked } 1\end{array}$ & 0 & 2 & 0 & 3 & 4 & 0 & 1 & 1 & 1 & 8 & 2 \\
\hline
\end{tabular}

TABLE X. COURSE EXIT SURVEY FOR COURSE OUTCOME - II

\begin{tabular}{|c|c|c|c|c|c|c|c|}
\hline Lesson Outcomes for CO1 & LO1 & LO2 & $\mathbf{L O 3}$ & LO4 & LO5 & LO6 & $\begin{array}{c}\text { The average number of } \\
\text { students for } \mathrm{CO2}\end{array}$ \\
\hline $\begin{array}{c}\text { Total Number of Students Participated in } \\
\text { Survey }\end{array}$ & 54 & 54 & 54 & 54 & 54 & 54 & 54 \\
\hline $\begin{array}{c}\text { Total Number of Students who have marked } \\
4\end{array}$ & 34 & 31 & 25 & 27 & 21 & 28 & 28 \\
\hline $\begin{array}{l}\text { Total Number of Students who have marked } \\
3\end{array}$ & 15 & 13 & 25 & 26 & 29 & 21 & 22 \\
\hline $\begin{array}{l}\text { Total Number of Students who have marked } \\
2\end{array}$ & 3 & 8 & 1 & 0 & 2 & 5 & 2 \\
\hline $\begin{array}{l}\text { Total Number of Students who have marked } \\
1\end{array}$ & 2 & 2 & 3 & 1 & 2 & 0 & 2 \\
\hline
\end{tabular}

TABLE XI. COURSE EXIT SURVEY FOR COURSE OUTCOME -III

\begin{tabular}{|c|c|c|c|c|c|c|c|c|c|}
\hline Lesson Outcomes for CO1 & LO1 & LO2 & LO3 & LO4 & LO5 & LO6 & LO7 & LO8 & $\begin{array}{l}\text { The average number of } \\
\text { students for } \mathrm{CO3}\end{array}$ \\
\hline $\begin{array}{l}\text { Total Number of Students } \\
\text { Participated in Survey }\end{array}$ & 56 & 56 & 56 & 56 & 56 & 56 & 56 & 56 & 56 \\
\hline $\begin{array}{c}\text { Total Number of Students who have } \\
\text { marked } 4\end{array}$ & 38 & 29 & 29 & 28 & 33 & 26 & 32 & 31 & 30 \\
\hline $\begin{array}{c}\text { Total Number of Students who have } \\
\text { marked } 3\end{array}$ & 18 & 27 & 22 & 38 & 23 & 31 & 24 & 26 & 26 \\
\hline $\begin{array}{c}\text { Total Number of Students who have } \\
\text { marked } 2\end{array}$ & 0 & 0 & 3 & 0 & 0 & 1 & 0 & 1 & 0 \\
\hline $\begin{array}{c}\text { Total Number of Students who have } \\
\text { marked } 1\end{array}$ & 0 & 0 & 2 & 0 & 0 & 0 & 0 & 0 & 0 \\
\hline
\end{tabular}

TABLE XII. COURSE EXIT SURVEY FOR COURSE OUTCOME -IV

\begin{tabular}{|c|c|c|c|c|c|c|c|c|}
\hline Lesson Outcomes for CO1 & LO1 & LO2 & LO3 & LO4 & LO5 & LO6 & LO7 & $\begin{array}{c}\text { The average } \\
\text { number of } \\
\text { students for } \\
\text { CO4 }\end{array}$ \\
\hline $\begin{array}{c}\text { Total Number of Students Participated in } \\
\text { Survey }\end{array}$ & 51 & 51 & 51 & 51 & 51 & 51 & 51 & 51 \\
\hline Total Number of Students who have marked & 25 & 23 & 28 & 24 & 21 & 19 & 27 & 24 \\
\hline $\begin{array}{l}\text { Total Number of Students who have marked } \\
3\end{array}$ & 24 & 21 & 17 & 24 & 21 & 18 & 24 & 21 \\
\hline $\begin{array}{l}\text { Total Number of Students who have marked } \\
2\end{array}$ & 2 & 5 & 5 & 3 & 9 & 10 & 0 & 5 \\
\hline $\begin{array}{l}\text { Total Number of Students who have marked } \\
1\end{array}$ & 0 & 2 & 6 & 0 & 0 & 4 & 0 & 1 \\
\hline
\end{tabular}




\begin{tabular}{|c|c|c|c|c|c|}
\hline Lesson Outcomes for CO1 & LO1 & LO2 & LO3 & LO4 & $\begin{array}{c}\text { The average number of } \\
\text { students for CO5 }\end{array}$ \\
\hline Total Number of Students Participated in Survey & 49 & 49 & 49 & 49 & 49 \\
\hline Total Number of Students who have marked 4 & 31 & 36 & 37 & 38 & 36 \\
\hline Total Number of Students who have marked 3 & 10 & 12 & 12 & 10 & 11 \\
\hline Total Number of Students who have marked 2 & 8 & 1 & 0 & 1 & 2 \\
\hline Total Number of Students who have marked 1 & 0 & 0 & 0 & 0 & 0 \\
\hline
\end{tabular}

TABLE XIV. CONSOlIDATED COURSE EXIT SURVEY

\begin{tabular}{|c|c|c|c|c|c|}
\hline Course Outcome & $\begin{array}{c}\text { Number of } \\
\text { Students } \\
\text { Participated in } \\
\text { Survey }\end{array}$ & 4- Very Good & 3- Good & $\begin{array}{c}\text { 2- } \\
\text { Satisfactorily }\end{array}$ & 1- Poor \\
\hline Course Outcome - I & 58 & 26 & 25 & 5 & 2 \\
\hline Course Outcome - II & 54 & 28 & 22 & 2 & 2 \\
\hline Course Outcome - III & 56 & 30 & 26 & 0 & 0 \\
\hline Course Outcome - IV & 51 & 24 & 21 & 5 & 1 \\
\hline Course Outcome - V & 49 & 36 & 11 & 2 & 0 \\
\hline
\end{tabular}

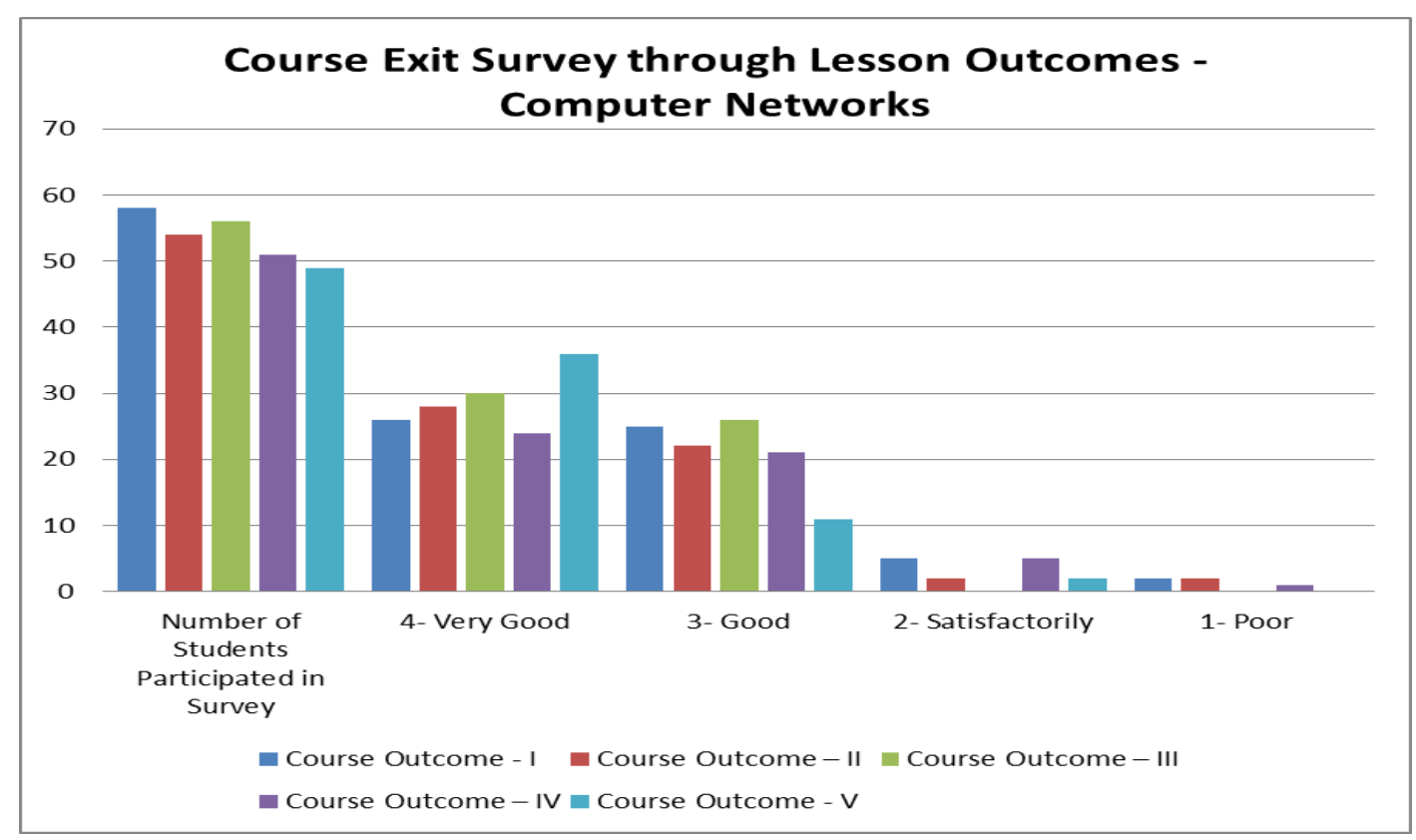

Fig. 2. Graphical Representation of Course Exit Survey through Lesson Outcome

\section{Conclusion}

The research proposed the mapping of course outcomes to lesson outcomes by taking computer networks as a sample course with the analysis of the results through the course exit survey. Since the problem of course outcome is a scope which covers multiple topics. Some of the slow learners take time to understand a particular topic of same course outcome. Since assessment is generally based upon course and not on an individual topic, it is almost unpredictable for a course teacher to find out students that which topic is very difficult to understand. Dividing course outcome into lesson outcome ensures that students have understood each topic and results can be produced later on.

To conclude from results and discussions, it is observed that $87.93 \%$ (rating 3 and 4) students understood the outcome of the lesson of Course Outcome- I. $92.59 \%$ Students understood the outcome of lesson of Course Outcome -II, $100 \%$ students understood the outcome of lesson of course outcome- III, $88.23 \%$ students understood the outcome of lesson of course outcome- IV, 95.91\% students understood the outcome of lesson of course outcome- V.

\section{FUTURE RESEARCH}

Future research can be summarized as follows:

- Preparation of laboratory outcomes along with lesson outcome for experimental subjects can help the student to understand practical concepts better. 
- Since this research only maps corresponding lesson outcome to course outcome, in the future research mapping of individual assessment tool with individual lesson outcome will provide for granularity in Outcome-Based Curriculum.

- Mapping of Lesson Outcome with the appropriate assessment method ensures the fruitfulness of the innovative method and students can be continually assessed.

\section{ACKNOWLEDGMENT}

The authors want to say a big thank you to NMIMS university for providing financial assistance to present papers at the conference. We want to thank our Head of the Department Dr. Pravin Shrinath for assigning this course to us for undergraduate students of NMIMS University.

\section{REFERENCES}

[1] Davis, M. H. (2003). Outcome-based education. Journal of veterinary medical education, 30(3), 258-263.

[2] Hussen, M. S. REVIEW ON FLEXIBLE AC TRANSMISSION SYSTEM COMPONENTS IN THE DEREGULATED POWER SYSTEM.

[3] Sekhar, C. R., Farook, O., \& Bouktache, E. (2008). Continuous improvement process based on outcomebased education. In Proceedings of The.

[4] Pattaguan, E. J. P. (2016). To Be on Top: A Sustained Outcomes-Based Accountancy Education Experience. Journal of Business Studies Quarterly, 7(3), 127.

[5] Linsangan, N., Santiago, R., Ballado Jr, A., Navalta, C. \& Caluyo, F. (2011). Shifting to outcomes-based education: The Mapúa Institute of technology experience. In Proceedings of the World Congress on Engineering and Computer Science(Vol. 1, pp. 19-21).

[6] Chaudhary, U., \& Chaudhary, A. NBA Document Management System an E-Self Assessment Report (ESAR) and Computing of Attainment Level of POs an API: OLTP-Software Subsystem.

[7] S. P. Mchunu, and S. N. Imenda, "The Effects of Traditional, Outcomes Based Education (OBE) and Blended Teaching Approaches in Alleviating Conceptual Difficulties and Alternative Conceptions in Grade Twelve Mechanics", Int J Edu Sci, 8(2): 333-343 (2015)

[8] Ron Brandt, The Technical Writer's Handbook. Mill Valley, CA: University Science, 1989.

[9] Churi, P., Mistry, K., Dhruv, A., \& Wagh, S. (2016, December). Alchemizing Education System by Developing 5 Layered Outcome Based Engineering Education (OBEE) Model. In 2016 IEEE 4th
International Conference on MOOCs, Innovation and Technology in Education (MITE) (pp. 338-345). IEEE.

[10] P. Churi (2017). TECHNOLOGY IN TEACHING: INDIA'S PERSPECTIVE. International Education And Research Journal, 3(7).

[11] Krathwohl, D. R. (2002). A revision of Bloom's taxonomy: An overview. Theory into practice, 41(4), 212-218.

[12] Sosniak, L. A. (1994). Bloom's taxonomy. L. W. Anderson (Ed.). Chicago, IL: Univ. Chicago Press.

[13] Oliver, B., Jones, S., Ferns, S., \& Tucker, B. (2007). Mapping curricula: ensuring work-ready graduates by mapping course learning outcomes and higher order thinking skills. In $A$ conference for university teachers (p. 103).
[14] Poole, D. L., \& Davis, T. S. (2006). Concept mapping to measure outcomes in study abroad programs. Social Work Education, 25(1), 61-77.

[15] Lam, B. H., \& Tsui, K. T. (2013). Examining the alignment of subject learning outcomes and course curricula through curriculum mapping. Australian Journal of Teacher Education (Online), 38(12), 97.

[16] Lam, B. H., \& Tsui, K. T. (2016). Curriculum mapping as deliberation-examining the alignment of subject learning outcomes and course curricula. Studies in Higher Education, 41(8), 1371-1388.

[17] Veltri, N. F., Webb, H. W., Matveev, A. G., \& Zapatero, E. G. (2011). Curriculum mapping as a tool for continuous improvement of IS curriculum. Journal of Information Systems Education, 22(1), 31.

[18] McKenzie, M. D. (2000). How are adventure education program outcomes achieved?: A review of the literature. Journal of Outdoor and Environmental Education, 5(1), 19-27.

[19] Rajak, A., Shrivastava, A. K., \& Shrivastava, D. P. (2018, November). Automating Outcome Based Education for the Attainment of Course and Program Outcomes. In 2018 Fifth HCT Information Technology Trends (ITT) (pp. 373-376). IEEE.

[20] Fitzallen, N., \& Brown, N. R. (2017). Outcomes for engineering students delivering a STEM education and outreach programme. European Journal of Engineering Education, 42(6), 632-643.

[21] Radermacher, A., \& Walia, G. (2013, March). Gaps between industry expectations and the abilities of graduates. In Proceeding of the 44th ACM technical symposium on Computer science education (pp. 525530). ACM.

[22] Pavon-Marino, P., \& Izquierdo-Zaragoza, J. L. (2015). Net2plan: an open source network planning tool for bridging the gap between academia and industry. IEEE Network, 29(5), 90-96.

[23] Beckman, K., Coulter, N., Khajenoori, S., \& Mead, N. R. (1997). Collaborations: closing the industryacademia gap. IEEE software, 14(6), 49-57.

[24] Melese, T., Lin, S. M., Chang, J. L., \& Cohen, N. H. (2009). Open innovation networks between academia and industry: an imperative for breakthrough therapies. Nature medicine, 15(5), 502.

[25] Yen, D. C., Chen, H. G., Lee, S., \& Koh, S. (2003). Differences in perception of IS knowledge and skills between academia and industry: findings from Taiwan. International Journal of Information Management, 23(6), 507-522.

[26] Norman, D. A., \& Spohrer, J. C. (1996). Learnercentered education. Communications of the ACM, 39(4), 24-27.

[27] Oblinger, D. (2004). The next generation of educational engagement. Journal of interactive media in education, 2004(1).

[28] Harden, R. M. (1999). AMEE Guide No. 14: Outcomebased education: Part 1-An introduction to outcomebased education. Medical teacher, 21(1), 7-14.

[29] Spady, W. G. (1994). Outcome-Based Education: Critical Issues and Answers. American Association of School Administrators, 1801 North Moore Street, Arlington, VA 22209 (Stock No. 21-00488; \$18.95 plus postage).

[30] Shuman, L. J., Besterfield-Sacre, M., \& McGourty, J. (2005). The ABET "professional skills"-Can they be taught? Can they be assessed?. Journal of engineering education, 94(1), 41-55.

[31] Felder, R. M., \& Brent, R. (2003). Designing and teaching courses to satisfy the ABET engineering criteria. Journal of Engineering Education, 92(1), 7-25. 
[32] Chan, E. Y., Guo, C., Huang, Z., Chan, G. K., Ho, H. H., \& Ho, J. Y. (2017). An Analysis of Student Engagement Patterns and Course Outcomes in a Public Health and Disaster Online Course. Prehospital and Disaster Medicine, 32(S1), S202-S203.

[33] Crow, G. M., \& Whiteman, R. S. (2016). Effective preparation program features A literature review. Journal of Research on Leadership Education, 11(1), 120-148.

[34] Kyndt, E., Gijbels, D., Grosemans, I., \& Donche, V. (2016). Teachers' everyday professional development: Mapping informal learning activities, antecedents, and learning outcomes. Review of educational research, 86(4), 1111-1150.

[35] Griffin, P., \& Care, E. (Eds.). (2014). Assessment and teaching of 21st century skills: Methods and approach. Springer. 